ARTICLE

DOI: $10.1057 /$ s41599-017-0022-3

\title{
On the elementals and their qualities in David Foster Wallace's Derivative Sport in Tornado Alley
}

Alexander Kozin ${ }^{1}$

ABSTRACT This article addresses the phenomenological concept of the 'world', the ancient Greek notion of the 'elementals' as well as their empirically accessible derivatives ('qualities'). These concepts are examined from the philosophical perspective, with David Foster Wallace's essay Derivative Sport in Tornado Alley serving as an illustration. The purpose of the examination is to show how the world communicates itself through its basic structures and their qualities to a child who is engaged in play. The works of Edmund Husserl, Martin Heidegger, and the Presocratics assist this study with a methodological framework. The provisional findings include the significance of the elementals (fire, water, earth, and air) for the perception of the world and its structures, as well as the role of 'wind,' which is presented as a quality of the elemental 'air' and, in a different interpretation, as a divinity. The collusion between a mortal and wind, with sky and earth forming the background for this relationship, produces unique circumstances for playing tennis in a place, which constantly challenges this activity. The notions of 'childhood' and 'nostalgia' are also touched upon, albeit in a cursive manner. This study is designed to show advantages of employing phenomenology and ancient Greek philosophy for the humanities in general and specifically for the analysis of contemporary literature.

\footnotetext{
${ }^{1}$ University of Sussex, Brighton, UK. Correspondence and requests for materials should be addressed to A.K. (email: ak578@sussex.ac.uk)
} 


\section{Introduction}

$\mathrm{t}$ has become common for the humanities to associate the person with the world and not just to associate him or her but to claim that he or she is always already connected to the world. The latter formulation points to the works of Edmund Husserl, revealing the phenomenological origin of this orientation. From this perspective, one may speak about phenomenology being a source for the humanities, be it the 'new' sociology, history, descriptive psychology, or literature; hence, the main objective of this article: to strengthen the relationship between phenomenology and the humanities, with literature standing for the latter. I say 'strengthen' instead of 'establish' because this relationship has a long history of collaboration. ${ }^{1}$ More specifically, I would like to show how a non-fictional literary work can respond to the phenomenological method by showing how the world communicates itself to a child by disclosing its structural make-up. Once disclosed, the structures of the world cannot but affect the human subject sometimes in a negative and sometimes in a positive way, for example, by aiding a child who is playing tennis, as David Foster Wallace depicts it in his 'Derivative Sport in Tornado Valley.' In order to explore this thesis, I would like to first present Husserl's concept of the 'world,' extend this concept with the Presocratics and then seek an elaboration from Martin Heidegger, thus showing the place of the four elementals (fire, water, earth, and air) in this world, with a specific focus on elemental qualities. I end by localizing the latter in the notion 'wind,' which is one of the protagonists of David Foster Wallace's essay.

\section{The world: a phenomenological perspective}

I begin with the phenomenological concept of the world not only because it is a foundational concept for phenomenology, but also because Wallace's essay begins with the description of his world that he experienced as a child playing tennis in Central Illinois. Since Wallace's literary treatment of 'world' is not a philosophical one, I find it necessary to turn to phenomenology for a stricter conceptualization. According to Edmund Husserl, we live in the world which is filled with objects of all kinds. This makes the world objective but this does not mean that it is objectively static. On the contrary, for a perceiving person, it is always in the state of flux, for he or she is always affecting (constituting) and is being affected (constituted) by the world. The world is therefore a living world. In order to underline this thesis, Husserl calls it the lifeworld (Lebenswelt). He defines it as 'the universe of life-world objects' (1970, p 173). It is also a communicating world because it is the ground and source of all meaningfulness on the one hand and the origin of multiple communal worlds on the other. Although communal worlds are distinctly different from each other, they all belong to the life-world. For example, a family is one such world, a nation is another. There is also a universe of individual worlds, starting from the world of food and eating and ending with the world of work and work relations. Some worlds pre-exist, but they can also be handed over (such as the rules of a game which can be explained to an uninitiate), others can be created, still others only imagined or intuited. An objective world of architecture is the first kind of world, a criminal underworld belongs to the second type, while a literary work to the last one. Since phenomenology does not insist on a clear-cut distinction between material and immaterial worlds on account of one's constant attending outside of oneself, the two kinds of worlds can be imagined as always connected in the same way a living body is connected to non-living objects. For example, in play, people are not only engaged in the same activity, they often define this activity by the physical parameters of their immediate environment and the objects required for this activity to take place. Take tennis for an example. The game can be approached as a small world because it is restricted to a place (tennis court), involves abstract rules (as in the relationship between a ball and the ground), concrete actions (such as serving a ball, as well as returning it) and several kinds of objects (for example, net, ball, racket). Importantly, our attending to this kind of a world falls not only on the objects themselves but also on the conditions which make these objects meaningful, for example, the weather and other natural circumstances.

However, normally, we perceive objects, human bodies and their actions as manifestations that show themselves by themselves, as it were. Husserl calls this way of experiencing the world 'the natural attitude.' The natural attitude permeates our everyday living. Its main task is to deproblematize the life-world, concealing the conditions for its existence behind the acts of deproblematization. In collusion with the natural attitude we find natural sciences which help conceal the 'true' meaning of the lifeworld. Natural sciences are also responsible for posing a substitute for the life-world and its structures, offering instead its explanation in abstract terms, outside of the subjective experience. For example, Husserl identifies two most basic or elementary transcendental structures that create the possibility of experiencing the life-world: 'earth-as-ground/world-as-horizon' and 'home-world/alien-world.' ${ }^{\text {, }}$ Both structures are essential for our experience. However, due to the pull of the natural attitude, we do not recognize the life-world as pre-structured, preferring to rely on the scientific inquiry when searching for the composition of this world. As a mode of inquiry, exact sciences make the lifeworld recede to the background, however, turning it into a problem at hand. Recovering the life-world's authenticity is the task undertaken by both Wallace and Husserl, although this task is being fulfilled on different grounds: Wallace does so from his own experience, while Husserl identifies the historical origin of the problem first. At the same time, both the writer and the philosopher are in agreement about the significance of nature for our understanding of the life-world.

Thus, in the last period of his work, which roughly embraced 1923-1936, Husserl suggested that the 'loss' of the life-world was not an original condition but had begun at a certain point in human history, at the end of Renaissance, when the life-world had changed its sense from being all-encompassing and infinite to the totality of mathematical predictability. As a result, the prescientific thinking about nature and natural forms underwent a drastic transformation, handing the reigns to the emerging sciences that saw in the ideal forms a multitudinal potential for infinite reproduction. In turn, by making the life-world explainable but also, more importantly, by making it appear before the naked eye, as it were, the logic of the ideal world began to distort the essence of the life-world as a world of natural forms. The turn of the inquiring consciousness to calculus created a particular kind of proximity which allowed the humans to attain the world in a rational, coherent and systematic manner. Following the development of chemistry, physics, and mathematics as fundamental disciplines, the overall scientific approach to the inexhaustible life-world changed: the world became available to the natural sciences for an in-depth examination as a natural object. In what follows, I would like to explain this transition with Husserl in terms of its relevance to Wallace's introductory part of his essay that deals with mathematics, as well as his use of mathematical terms throughout the description of his play-world. Importantly, my explanation implies that Wallace's personal history and the history of sciences coincide at the point of no return.

For Husserl, this point rises at the end of the 17th century when exact sciences began to dictate how to approach the world exhaustively as a whole. In order for this approach to become 
customary, a new definition of the world had to be created for the natural dweller. The humans had already redefined their world once before when arithmetic and Euclidean geometry were invented by the ancient Greeks, who presented ideality as an alternative to the life-world and its best explanandum. The perfection of geometrical forms was sufficient to imagine them to be the very conditions that defined our existence. Furthermore, Husserl argued that the earlier form of mathematization of the world was incomplete since it was direct, that is, it involved measurable and countable concrete objects such as land and metals. The notions of distance and weight were applied to these objects to determine them in praesentia, statically, from within themselves. The faculty of exactness as an art of measuring that belongs to mathematics and geometry alike paved a straight path to this destination. As soon as the art of measuring ceased to be attached exclusively to the ground it had been designed to measure, the ground itself lost its constitutive force, transforming a concrete experience of the life-world into a hypothesizing inquiry. In turn, for Wallace, a new period of his life marked a turn from the unreflective perception of a child to the mathematicallyminded view of the world accessible to a late adolescent. The history of his home place facilitated this transition: the introduction of the wind-breaking tarp for outdoor courts in the early 1970s was the beginning of the end for Wallace's world, which was the world of 'deformities.' The tarp did not only isolate the tennis court from the world at large, it eliminated the inner boundary of the playing space, and, with it, Wallace's personal set of lines: 'I was disabled because I was unable to accommodate the absence of disabilities to accommodate' (Wallace, 1997, p 15).

One can think of Galileo in the same way, as a historical event, but whether the introduction of the wind-breaker into the world of Wallace-the-child or the improvement of the telescope by Galileo were indeed essential for the advent of modernity is less important than the circumscription of ideality presented in the programmatic way for the first time by phenomenology and the reflection on one's play by Wallace. For one, Husserl suggested the so-called phenomenological path that would return live experience to its pre-mathematical, pre-predicative origin by replacing the natural attitude with the phenomenological one. Most important in this task is the concept of intentionality that connects the static and the genetic poles of experience, showing, without doubt, that ideality existed only as abstraction. Another equally powerful concept that undermined the natural attitude's clinging to the unproblematic living is intersubjectivity, because, having communication as its main operation, intersubjectivity makes the world multi-perspectival, rather than two-dimensional. Reducing the ideal world to a communicating world creates the ground for sociality on the one hand and helps avoid giving primacy to perfect forms in favor of imperfect experiences localized by face-to-face communication, including play. Moreover, the communicating world does not exclude the interaction between the natural world and the human world. Both are an inalienable part of the life-world. Wallace would have agreed with this characterization.

Indeed, communication constitutes this world and continuously enriches it: 'We, subjects of worldly experience, have an endlessly open world $[\ldots]$ through the others' mediation, and finally, their inter-communication' (Husserl, 1973, p 220). In this world a special role is designated to the child who, according to Natalie Depraz, is a 'communicating and intersubjective being from the beginning' (2001, p 170). As a subject, the child is enmeshed in the life-world to the extent that makes it a proper habitant of this world, which the child defines less by precision and prediction and more by intuition and spontaneity. An extra attunement to the world via empathy creates special connections and relations to nature that only the child can experience in full due to his or her 'abnormality.' This makes the child a 'natural phenomenologist' who communicates with his or her immediate environment without having to reflect on it (Welsh, 2013, p 17). Maurice Merleau-Ponty calls the child 'polymorphic' and defines its world as predominantly a world of play. According to him, only the child with its enhanced sense of 'the imaginary real' is capable of being immersed in that world completely (2010, p 136). In his essay, by employing literary imagination, Wallace describes his own childhood experience of playing tennis as an experience of being intimately connected to the world or rather to one of its qualities, namely, wind. In order to understand this connection, we need make a detour from phenomenology to ancient philosophy and engage the Presocratic view of the world that is structured somewhat differently than Husserl's notion; it had not yet undergone mathematization, allowing us to understand it mainly through the work of philosophical intuition, a quality which implicates the child directly. In my exposition of the Presocratics, I make a special emphasis on their treatment of air as the very elemental from which Wallace draws his description of wind.

\section{The Presocratics on the elementals}

In the history of philosophy the Presocratics assume a special position and not only because they invented philosophy as a way of being in thinking or, one can say, as a way of thinking about being, and not because their way of thinking begot Socrates, Plato, and Aristotle, who subsequently established philosophy as a rigorous discipline, but rather because their ideas about the world, nature, man, truth, and justice informed philosophy from day one, remaining a bottomless source of its nourishment up to these days. Unfortunately, the preserved scripts from the Presocratics, which date back to as early as the 6th century BC, consist mostly of incomplete excerpts, thus disallowing any definitive interpretation, suggesting instead that for the understanding of the early Greek thought one must necessarily rely on later interpretations in the contexts offered by Plutarch, Theophrastus, Aristotle, Simplicius, Diogenes Laertius, Hippolytus, Plato, and many other subsequent Greco-Roman historians and philosophers. These interpretations are united not by a systematic exposition of individual Presocratic philosophies but rather by the emphasis on their common way of thinking, which is not rational, at least when it comes to either common or formal logic, but paradoxical because this commonality is grounded in the union of logos and wonder, or the logos of wonder. ${ }^{3}$ At the core of the ancient concept of wonder lies the world; hence, the search for the understanding of the world that was pioneered by a select group of the Presocratics: Thales, Heraclitus, Parmenides, Anaximander, Xenophanus, and Empedocles. The latter are justly credited with seeing in the world spirituality of the human, ambiguity of the divine, and materiality of nature.

For the ancients, the thus imagined world was not amorphous or inaccessible; it was held together by a relational structure made from four root elements (fire, water, earth, and air). These elements or elementals were thought to be connected to each other spherically as multiple intersecting circles brought into motion by the dialectic of love and strife. In contrast to the Christian battle between good and evil, the relation between love and strife is neither antagonistic nor categorically uniform: strife belongs to nature, while love belongs to the divine and since divinities and humans depend on each other,-to men. For example, Empedocles maintains that love emerges from strife; its purpose is to collect 'all into one' (Diels and Kranz, 1903, [B 17]). ${ }^{4}$ In turn, strife separates, instigating a movement either upward or downward. In order for love to prevail over strife it must gather anew all that was taken away 'by the hatred strife' (Diels and Kranz, 1903, [B 17]). 
This part appears to do little with Wallace and even less with playing tennis. Yet, in the very beginning of his essay, Wallace mentions the reason for writing it: nostalgia, and, since nostalgia is often driven by love as in the love for the irrecoverable past, I find nostalgia to be pertinent for the understanding of how mathematics could come into strife with a childhood experience of playing, thus allowing Wallace to reflect on this experience: 'math dismantles memory and puts it in light' (1997, p 3).

In order to obtain love, continues Empedocles, man must go to see the 'blessed gods' (Diels and Kranz, 1903, [B 131]). For the Presocratics, only gods can grant 'true' love. Among the Greek gods, the most sought out is Aphrodite, 'a goddess who governs all things' and who was the first deity 'to devise love,' in the words of Parmenides (Diels and Kranz, 1903, [B 12]). Sometimes, gods dispense love on men just so (ancient Greek gods are emotional beings; their actions cannot be rationalized in accordance with some pre-given logical scheme); sometimes, only a journey allows men to obtain it. On the way to gods men encounter the very elementals ('fire, and water and earth and the boundless height of air'), which appear and act as guiding forces, according to Parmenides (Diels and Kranz, 1903, [B 17]). Sometimes they facilitate the journey and sometimes they prevent it. As the last section of this article is going to show, Wallace did not venture out to see gods. Instead, they visited him, appearing in the shape of benevolent forces. Since not all the manifestations are of relevance for Wallace, it might be pertinent to address the relationship between and among them. Upon reading the Presocratics back to back, it becomes clear that this relationship is as complicated as their distribution for there is no agreement between the Presocratics about which force is designated by which elemental and which elemental should be considered as the primary one in the set of four. For example, according to the secondary interpretation given by Aristotle, Thales insisted that earth rests upon water. For him water is undeniably the first elemental because of the fact that earth is in motion only because of water; it is therefore the key material principle of the world. The purpose of the elemental movement is to create life and fulfill soul. From this perspective, the Gods are paradoxical beings, claims Heraclitus, for they live inside an infinite pause; they are neither in motion, nor at rest. As for the primacy among the elementals, Heraclitus names fire as the first principle: 'Fire will come and judge and convict all things' (Diels and Kranz, 1903, [B 66]). Relationally, fire coheres best with water; it solidifies water, turning it into earth.

In addition, Heraclitus classifies water, fire, and air (ether) as secondary elementals, while identifying water as the prime mover, but in a characteristically paradoxical way. His famous dictum about 'no man is able to enter the same river twice' shows that his approach to elementals is metaphorical: he is less concerned with water as a foundational substance and more so with time and its paradoxes. For example, he suggests that (a) all things are one; (b) unapparent harmony is better than apparent; (c) the path up and down is one and the same; (d) the sea is both good and bad. Therefore, his contribution to the philosophy of the elementals is unclear, but the emphasis on the moving water in his examples is reminiscent of the emphasis on the moving air, which was made by Parmenides and which could have brought us straight to the discussion of wind, which is but air in motion. However, for Parmenides, the main elementals are fire and earth. He calls them 'principles' and distinguishes them on the basis of temperature: 'fire is hot while earth is cold' (Diels and Kranz, 1903, [B 8.53-59]). As the basic principles or, shall we say, conditions for the appearance of the world, these elementals move around one another in the manner of spherical bands. Of the mixed bands the middle one is the cause of all motion, but it is not an elemental. Rather it is the governing goddess-truth (aletheia), who is the 'key-holder for justice and necessity' (Diels and Kranz, 1903, [B 8.53-59]). As for other elementals Parmenides insists that air rises from the earth, vaporized by its violent compressions. In turn, the sun and the circle of the Milky Way are the 'breath of fire' (Diels and Kranz, 1903, [B 11]). The moon is a mixture of both - air and fire. The fact that Parmenides identifies air as the secondary element which is dependent (predicated) on earth might be beneficial for the argument about the reversal in the primacy of their appearance. Due to its direct association with movement, for men, air is the first to appear; as a shape shifter, it is also the longest to stay. Of interest here is a view on air espoused by Anaximenes who identifies air with a human soul: just as our soul, being air, holds us together, so do breath (pneuma) and air encompass the whole world' (Benso, 2008, p 14).

Finally, Empedocles mentions all four elements-fire, water, air, and earth-as being equally important because all of them are connected to the human soul. He says that the judgment of the bad takes place by the sea first, then comes earth, then fire, then air (the whirls of the ether)' (Diels and Kranz, 1903, [B 115.10-12]). Once again, the fleeting character of air puts it as the last of the four elementals, although it remains a full participant in the constitution of the world. This process is described as follows: the elements periodically unite into an all-encompassing sphere. After certain time passes, this sphere splits into four independent concentric circles, generating various unions and mixtures. But eventually all the elementals become fused into a homogenous sphere again. Importantly, for the connection to the previous section, Empedocles describes the periodic return and the destruction and then unification of one into many and many into one poetically: 'I shall tell a two-fold tale now about how they agree to be alone from many and how they grow apart again to become one-fire and water and earth and boundless height of air and how the curse of strife brings them apart from them balanced in every way and love among them, equal in length and breadth' (Diels and Kranz, 1903, [B 17]). Empedocles considers water, fire, earth, and air eternal (everything else comes into being from them, including man). Most importantly, they are eternal because they can inflict a change, bringing anything formless into a single form. They can exist separately because the world is neither empty nor full. The four roots also have proper names because they are personified in four corresponding divine figures: Zeus, Hera, Aidoneus, and Nestis (Diels and Kranz, 1903, [B 6]).

A wonder in this wondrous world, man enjoys a particular place for the Presocratics. He is not a centerpiece however. For example, Parmenides, who insists that the world would not have existed without man, allows for gods to exist in a world of their own. Empedocles adds to Parmenides by saying that man fits the world as both a creation, that is, a derivative from the divine, and a creator of things. More importantly, man is a creator of what he himself is not, which is art, and I must add, play. Only by having acquired the capacity of standing aside, man could employ the elements, their principles and functions, even if only in imagination, and then extend this creativity to an even higher pursuit: the pursuit of truth. Man needs truth not only to understand the world but also to be able to reflect on himself and to be able to judge himself and others. According to Parmenides, truth, justice, and necessity are the concepts that make the elementals speak for the human being, as it were. The Presocratic way of thinking can be therefore further defined as transcendental poetics, which does not mean that it was brought to the fore only to show the beauty of the world but also because it aspired to show its authenticity as a truth-bestowing universe (cosmos).

The above elaboration, no matter how brief, should nonetheless give us an alternative interpretation of the world and its composition. In comparison to Husserl, the Presocratics, who also 
presumed that the world consisted of certain co-foundational structures which conditioned our experience, understood these structures differently in at least three respects. First, their components were loosely co-dependent and did not produce stable pairs, whether in opposition or collaboration. At the same time, most Presocratics agree on the spherical relationship between and among the elements. Second, unlike the distinction between the world of nature and the social world, their elemental composition encompasses both, with the human being assuming a special, albeit not definitional, place in the world's make-up. Finally, the operation that unites the elements within the world is movement. All the Presocratics believed that the elements could both produce movement or be affected by it. For example, earth moves with water, while water moves fire; fire moves air, and air is moved with earth. What is not clear is the significance of the moved air or water for the humans. One may surmise this significance on the basis of our everyday experience; however, in order to understand the actual experience of the moved air, for example, it needs to be conceptualized first. For this reason, I would like to turn, for the final elaboration, to Martin Heidegger, whose concept of the 'fourfold' appears not only to retain the elements of the Presocratic thought (his lecture courses on the ancients, including Parmenides and Heraclitus, constitute a large number of his total published works), but also to unify them into a selfsustaining model. With the help of this model, we can also understand the place of 'quality' in relation to the elementals, thereby completing a theoretical trajectory on the way to Wallace's essay.

\section{Heidegger's 'fourfold'}

Heidegger introduces the 'fourfold' in relation to visual art and poetry. In that sense he does not only thematize the composition of the world in terms of one of the domains of experience, namely, imagination, he also explains it in terms of origin and nature not unlike Wallace, but he does so from a strictly phenomenological perspective and with a strong emphasis on truth. This emphasis should not hamper but advance out investigation by adding to it a greater precision. With Heidegger, the question about the composition of the world and the relations between and among different elementals acquires a modifier: How does the world communicate itself to a child through play originarily, that is, without a doubt? In his essay 'On the Origin of the Work of Art' Heidegger engages art as the shortest path to truth, singling out the poetic context as a stimulus for reassessing our experience of beauty. For him, art embraces both imagination and spirit and thus situates truth (meaning) in the symbolic realm, endowing it with productive ambiguity at the highest level of associative generativity. Since Heidegger examines art in phenomenological terms, he utilizes different kinds of evidence to argue for the communicative effects of art and its communicative effects. For him, truth is to be sought in the constitution of art as a phenomenon of the world. Coming from the world, art is aistheton (from the Ancient Grrek aesthesis = perception), or 'that which is perceptible by sensations in the sense belonging to sensibility' (Heidegger, 1971, p 25). It is also 'work,' and this is where the connection to David Foster Wallace transpires most vividly.

In the context of our examination, play too is work. This kind of perspective is justified by the inherent dynamism Heidegger espouses in his perspective on art, which 'is always a work even if it is something worked out, brought about, affected' (Heidegger, 1971, p 55). Similarly, child play is work because truth is embedded in it. Therefore, when Heidegger asks us if the phenomenon of art is a true phenomenon and therefore can set up its own meaningful world, we can replicate his question in relation to playing. We should ask then: What is it about the world that is being communicated by a playing child? In order to answer this question, it will be worthwhile to remind ourselves that Heidegger approaches the fourfold in both registers: static and genetic, which is a confirmation of Husserl's view of the structural makeup of the world. ${ }^{5}$ This also positions Heidegger closer to the Presocratics who endowed all their elementals with the ability to move (we can trace the same allusion to movement in Husserl, although it is associated with time consciousness and history rather than the world), exposing the world not only as spherical but also as revolving around itself. At the same time, in contrast to the Presocratics, whose model of the world privileges inward movement, Heidegger views the fourfold as an open system that tends outward on account of generativity. This means that in order to examine the fourfold, one must unwrap rather than reconstruct or re-cover it, starting with the notion of work. For Heidegger, work needs to be resolved in the form of sumballein. Importantly, as Heidegger explicitly points out, one must not confuse sumballein with symbolism, and Heidegger is quite explicit in that respect. If the symbolic is given by way of 'standing for,' sumballein is more of a residue, a trace of 'something else' that comes about when a work of art is brought together. This 'something else' is not an elemental or an entity; it is not even a structure but a quality. Quality is derived from the elementals; it is also what makes them present, just like wind makes air present.

With this, Heidegger's fourfold expands the Presocratic model; it also has four components, but his 'elements' are of a different kind. They are sky, earth, mortals, and immortals or divinities. These elements have different weight and purpose. Their distribution is presented by Heidegger as pair-parts, resembling Husserl's structures 'earth-as-ground' and 'world-as-horizon.' For example, sky and earth are juxtaposed with each other, with sky pairing up with divinities, while earth is linked to mortals. In contrast to abstract mathematical symbols, which exist only within the rules of calculus, Heidegger's four 'folds' are actual phenomena available to experience. This also applies to the term 'divinity,' largely owing to Heidegger's untraditional use of this term. Perhaps they can be called meta-phenomena, or modifications of the elementals, since they too can be defined as mixed material/immaterial structures of existence. Similarly to the understanding of the elementals by Empedocles, Heidegger approaches the four elemental folds as progressively joined domains; hence, his methodological anchor: techne, which means 'bringing forth by means of unfolding' (Heidegger, 1971, p 57).

Each domain, whether it connects to earth or divinities, is a set place in the sense of the German notions of Stellen, Gestalt, and their Greek analog morphe. The relationship between and among the folds is stratified: immortals are preceded by sky, which is in turn preceded by mortals who originate from earth, which makes it the original domain and the first signification. The mode of unfolding discloses the works of stratification starting with earth, thus exposing the primary stratum of the original phenomenality. Incidentally, Wallace's description of his home place also begins with earth. Back to Heidegger, unfolding means the clearing a way for the appearances that come through the open, become unconcealed. It is from that perspective that, for a phenomenologist, 'bringing-forth' is both a symbolic quest and a creative activity. The unfolding is designed to bring us to truth (aletheia), which is a divine being for the ancient Greeks. The encounter with this being discloses not just the meaning of the world; it also shows the immortal associated with that meaning, as Heidegger describes it in his lecture course Parmenides. In either case, the journey to the world begins with the most familiar: 'the earth, the sheltering agent' (Heidegger, 1971, p 41).

The earth's ground is juxtaposed to the divine openness, which is sky. The openness of earth is concealing, it keeps things to 
itself. In contrast, sky is unconcealment. It completes the fourfold by 'gathering of the bringing-forth' (Heidegger, 1971, p 83). Earth grounds us, earth dwellers, in more than one way. It grounds by defining and adjusting our biology and thus our relations to the non-human world; yet it is also the ground on which we stand and walk and conduct our everyday affairs. We do so 'naturally,' writes Heidegger, thus drawing the border between the natural attitude and the phenomenological attitude. The division between the two calls us to begin the quest for truth by leaving the natural attitude, and, by abandoning its shelter, lets us hear the world. The act of hearing should not be understood literally. 'It is what opens up the world and keeps it abidingly in force' (Heidegger, 1971, p 43). Only when we learn how to suspend the natural attitude, albeit temporarily and never completely, we become able to understand ourselves and the world of immortals. Being open to this world, whether through art or play, means to experience sky, earth, and divinities as symbolic qualities. Thus, sky can be experienced as light, earth as mountains, and divinities as the movement of the elementals. Movement is therefore the necessary condition for the qualities to expose the corresponding elementals, just like the Presocratics had it. There is no specific shape or form in which the elementals would appear by themselves, but they will always come as things familiar to us, making it difficult to notice them and their meaning. However, it is the easiest for a child to be affected by them, as I would like to demonstrate with David Foster Wallace in the next section.

\section{Derivative Sport in Tornado Alley}

The above essay is one of the earlier works by David Foster Wallace published in 1992. Its original title was "Tennis, Trigonometry, Tornadoes." It was edited by the author under a new title in 1997 for a collection of non-fiction titled "A Supposedly Fun Thing I'll Never Do Again." The essay tells the reader about an experience of a boy (DF Wallace), who excels at playing tennis in Central Illinois, which is known for its strong and unpredictable wind. The writer's understanding of how to collaborate with wind contributes to a unique way of playing tennis which I describe further below. The essay is written in a style which brings to the fore Wallace's personal experiences. As it is common for the author, these experiences are described in great detail with special attention given to technical and local terms, including precise proper names. For this reason, Wallace's non-fiction can be called autoethnographic. It can also be called quasiphilosophical because Wallace tends to reference a number of philosophers, including Plato and Aristotole, but does so not with the purpose of advancing philosophy. Rather, he employs philosophy to advance literature. The latter emphasis makes his prose particularly appealing for this article that seeks a union between philosophy and the humanities.

Wallace begins his essay with the juxtaposition of his new home in Massachusetts and his newly acquired skill of mathematics he learnt as a college student in his father's alma mater to the place where he was born and raised-Philo, Central Illinois. The first place is a place where grown-ups dwell. They learn from professors and books and become very good at what they do, as is the case with Wallace, who majors in literature but takes mathematics as his minor. Or they abandon their pursuits of mastering exactitude, because, as was suggested in the beginning of this article, the pull of the life-world becomes too strong, or shall we say, with the Presocratics, because, at some point, love overcomes strife. For Wallace, this point occurred when nostalgia ('home sickness') made him stop looking for truth 'inside vectors, and lines, grids...' (Wallace, 1997, p 3), taking him back to the memories of his homeland, where he grew up 'on the scale of horizons, broad curving lines of geographic force,' and his knowledge of this land ('The area behind and below these broad curves at the seam of land and sky I could plot by eye way before I came to know infinitesmals as easements, an integral as schema'), which appeared more complex, upon reflection, than mathematics; in comparison to it, 'calculus was quite literally child's place' (Wallace, 1997, p 3). Returning to the beginning of this article, we might remember Husserl's definition of the world as well his critique of its mathematization imposed on the world by the natural sciences. Indeed, as one keeps on reading the essay, it becomes clear that Wallace, without discarding mathematics, is after an experience of the world which could be compared to math but not explained by it.

Importantly, the references to mathematics we encounter in the essay are poetic rather than conceptual (for example, when describing a tornado as a transformation, he mentions Descartes, Leibniz, and the ancient Greeks, but does so in passing without burdening the reader with models or quotes), and the world which he presents past his home-place is hardly the life-world; rather it is a world of play Wallace calls this world 'the Whole Court' (1997, p 14). The 'Whole Court' is located in Philo, which, when described mathematically, should be reminiscent of a math table: 'nine north-south streets against six northeast-southwest, fifty one slanted cruciform corners (the east and west intersection angles' tangents could be evaluated integrally in terms of their secants)' (Wallace, 1997, p 8). The play-world is not only a compressed miniature version of the town, it is also self-contained, a place within a place, it is still its own place, which is a perception natural for a child. Another peculiarity of the place is the atmosphere that surrounds the court: "The summer heat and wet-mitten humidity, the grotesquely fertile soul that sends grasses and broadleaves up through the court's surface by main force, the midges that feed on sweat and the mosquitoes ...' (Wallace, 1997, p 4). It is a messy unpredictable world devoid of certainty and precision. It is also the world which lets Wallace be good at something he is not meant to excel given his puny physique. What makes him good is not his stamina or tolerance to the bleaching sun and the endless horizon; rather, it is a different kind of math, the 'intuitive math,' which cannot be learnt, but only known.

With the help of the 'intuitive math,' Wallace-the-child was able to hit the ball 'from pretty much anywhere in the court' (Wallace, 1997, p 4). He ascribes his uncanny ability of 'knowing the court' to his ability of figuring the proclivities of wind, a local wonder. In the world composed of the elementals, wind comes up on the side unless it itself is approached as a quality of air, as I suggested in the section on the Presocratics. For Wallace, only air figures, however. Like sky and earth, it constitutes the Midwestern landscape, adding blinding brightness to the immense flat surface of the earth and the ever receding sky. It is therefore between sky and earth that the staging of the world of playing tennis takes place. Following the Presocratics, we can say that sky and earth are indifferent to each other, and Wallace is indifferent to them, apart perhaps from a note on the corroded surface of the courts in Illinois. The corrosion is caused not by water, explains Wallace, but by the assumption that the flatness of the ground would serve as a sufficient reason for just simply placing asphalt on top of the dirt without having to level it up. The result is usually a 'slight list,' a deformity caused by wind that strains earth by 'moving' it underneath the artificial cover. Thus, if sky and earth provide but the background for the play, the real figure of the play is the quality of air in Central Illinois, or, to be more correct, the movement of air, which is incessant: 'Most people in Philo didn't comb their hair because why bother [...] Wind, wind, etc.' (Wallace, 1997, p 5). The omnipresence of wind as well as its effects makes one take sides: for or against it. For Wallace-thechild, the wind is a living entity. He describes it as 'having a 
personality, a (poor) temper, and, apparently agendas' (Wallace, 1997, p 4). It is not just an incessant, definitional, and destructive matter, nor is it simply a hindrance, an annoyance, even an outrage; rather, it is a participant in the lives of the locals and a personal friend of little David.

How shall we understand wind as a quality? Wallace's answer to this question points to religion, although his view of religion is an untraditional one. When comparing the wind in Central Illinois with the wind of the Windy City, Chicago, Wallace calls 'his' wind 'a religious-type wind' (1997, p 5). One has to worship this wind in the same way people worship the river Gang or the Mount Fuji. The wind in the American Midwest flows like a river, constantly, sometimes speeding up and sometimes slowing down in its course. In that regard, it replaces the element that does not show up in the essay in any meaningful way: water. Indeed, Central Illinois is known for its droughts. Water is therefore a desirable entity. Paradoxically, the shortage of water makes wind more prominent as if it takes upon itself some of the quality reserved only for water. For example, wind produces a sound akin to the fast moving river, which is 'a low constant roar and the massive clicking [...] a soundtrack to life in Philo' (Wallace, 1997, p 6). Another paradox about wind deals with its constancy because of which the wind in Illinois is not registered by the locals as a wind, but as a dream-inducing silence, similarly to how we experience the metallic clicking of the joints that link the carriages of the train in motion. Wind that cannot be heard is air, an elemental, no longer a quality.

But returning to the discussion of religion in relation to wind, Wallace specifies his 'religious' experience of wind in Zen-like terms (to know and understand the Illinois wind, one must let all the presuppositional values go, receding into a primitive system of believes, which is more akin to myth and which is certainly pre-religion): 'I had gotten so prescient at using stats, surface, sun, gusts, and a kind of Stoic cheer that I was regarded a kind of physical savant, a medicine boy of wind and heat' (Wallace, 1997, $\mathrm{p}$ 11). This is where the connection to Heidegger's fourfold becomes particularly strong. A quality before, a near elemental, the wind turns into a divinity and Wallace into its beneficiary, whose special, albeit intuitive relationship to wind, allows him not only to play like a kid savant, outplaying stronger, and more experienced players, but also to feel like being in collusion with wind, as Odysseus was in relation to his protector Athena. Like Odysseus, Wallace does not control wind, he simply 'employs' it in his matches. Odysseus who calls Athena for advice is also 'employing' her to his end: Wallace's home coming, that is, his victories, were never just 'deserved.' Rather, they were 'just so,' happening at the pace set by wind, where the Taoistic way of controlling the world without controlling it meant a supreme form of action.

Everything comes to an end however, and as Wallace grows older, his relationship with wind becomes less certain. No longer a child, he sees his 'mastery' of wind on the court dwindle until 'his' wind actually turns on him. No reason for that change of attitude on the part of wind is specified or needed. It happened without any warning, reminding us of the capricious ancient Greek Gods, who change their relationships with the humans as they please. The loss of the divinity who befriended Wallace occurred at the end of the story, when a huge tornado rips through the court where Wallace and his friend are playing an evening match. Not only there is no tornado siren, 'there is no funnel either' (Wallace, 1997, p 19). It is just that everything got still, making the boys gasp for air. Then came the 'wave.' It leveled the court and, with it, the boys, sending them straight into the mesh fence, which the tornado leveled as well. As Wallace describes this kind of wind, he mentions that 'Tornados are omnipotent and obey no law. Force without law has no shape, only tendency and duration' (Wallace, 1997, p 17). From just air to the moving air, or wind, the quality of air became some unbridled force aimed at destroying everything in its way. A sheer force. The tornado story concludes Wallace's essay, as well as his special friendship with wind. Abandoned by it, Wallace admits that after the incident his play stopped improving, signifying a time of transition. Unlike the gift of Zephir to Odysseus, there was no accident that made wind escape his master, who was sent back for years due to his servant's curiosity. The world simply stopped communicating to the boy in a special way, destroying his play and ending his childhood. A few years later Wallace will be moving to Massachusetts, while his wind will remain in Central Illinois, replacing 'intuitive mathematics' with proper math, leaving the protective divinity to a mere childhood nostalgia.

\section{Conclusion}

In conclusion, I would like to recover the main points produced by this article. One point deals with Edmund Husserl's phenomenological perspective on the world. From this perspective, the world appears as a pre-structured whole (the life-world), which both informs all our experience and is informed by it. Its structures can be perceived and examined on both levels: 'earthas-ground' and 'world-as-horizon' as transcendental structures, while 'home-world' and 'alien-world' as quasi-empirical. The non-recognition of this postulate results in the approaching of the world as an object, leading to its mathematization by natural sciences. In order to return a proper sense to the life-world, human sciences have to rely on their own modes of inquiry some of which date back to the ancient times. For this article, particularly pertinent are the Presocratics, who took the elementals (air, water, fire, and earth) for the living structures of the world. Their emphasis provided a conceptual re-orientation to how one would want to approach the world. At the same time, due to some problems with exposition, the Presocratics required a further elaboration, which was found in Martin Heidegger, whose phenomenological hermeneutics unified Husserlian and Presocratic thought on the grounds of a hybrid model, which included mortals and their opposites: divinities. The encounter between mortals and divinities created the conditions for disclosing the world in one or several of its facets as qualities or empirical extensions of the elementals. In sum, Heidegger's intervention was necessary for showing the world in action as a communicating world.

My interpretation of Wallace's essay, which was carried out on the basis of all the above conceptual orientations, revealed the key quality that allowed Wallace as a child to play tennis as if he was assisted by the world, or rather one of its elemental qualities, namely, wind. The collusion between wind and a child player instigated a special relationship, where wind was not just a part of the nature or the local climate but a friendly divinity, which came to communicate a special way of playing tennis to a child. Later in his life, Wallace would compare the play-world of his childhood to his newly acquired mathematical proclivities only to discover that in comparison with his encounter with wind as a force that can be befriended, algebra is insignificant. He also discovered that when imposed on nature, mathematics receded before the sheer unpredictability of the world, which is never inaccessible as a whole but only by way of communicating with it, which results, as was the case of Wallace-the-child, in the world's becoming unconcealed, exposing truth about itself. Even when Wallace's special relationship ended, and wind no longer assisted in making the child's game special, the revelation about the significance of the world remained as an embodied memory, making him equally good at something that is farthest removed from the world he knew as a child. 
Received: 26 June 2017 Accepted: 10 October 2017

Published online: 31 October 2017

\section{Notes}

1 Suffice it to mention in this regard Sartre, Derrida, Deleuze, Ingarden, and, most importantly, Heidegger, who figures strongly in this essay.

2 For an in-depth elaboration of these structures, see Steinbock (1995).

3 The notion of wonder (thaumazein) in relation to ancient philosophy is explored by Staehler who argues that wonder signified the 'origin of philosophy' even for us (2017, $\mathrm{p}$ 120). In turn, Broadie comments on the paradoxical character of early Greek philosophy by calling it rational theology on account of its combining 'cosmological reasoning' with 'piety before gods' (1999, p 220). In addition, Held (1980) postulates that the Presocratics were particularly interested in such notions as 'substance' and 'change'; however, they conducted their discourse on these topics from within the prepredicative sphere which meant a combination of myth and logic.

4 The quotes from the Presocratics are presented using the numbering by Diels and Kranz (1903). Kirk and Raven (1957), as well as Barnes (1987) were consulted for the English translation.

5 The distinction is Husserlian. With it, Husserl separates two different ways of approaching the world: as origin and as structure (see his On static and genetic phenomenological method. In: Husserl E (2001) The 'analysis concerning active and passive synthesis. Lectures on transcendental logic', Steinbock AJ (trans). Kluwer Academic Publishers, The Hague, p 605-634).

\section{References}

Barnes J (1987) Early Greek philosophy. Penguin, London

Broadie S (1999) Rational theology. In: Long AA (ed) The Cambridge companion to early Greek philosophy. Cambridge University Press, Cambridge, p 205-224

Benso S (2008) The breathing of the air: Presocratic echoes in Levinas. In: Benso S, Schroeder B (eds) Levinas and the ancients. Indiana University Press, Bloomington, pp 9-23

Diels H, Kranz W (1903) Die Fragmente der Vorsokratiker. Weidmann, Berlin

Depraz N (2001) The Husserlian theory of intersubjectivity as alterology. J Conscious Stud 8(5-7):169-78

Held K (1980) Heraklit, Parmenides und der Anfang von Philosophie und Wissenschaft: Eine phämenologische Besinnung. De Gruyter, Berlin

Heidegger M (1971) The origin of the work of art. In: Hofstadter A (trans) Poetry, Language, Thought. Perennial Classics: New York, p 15-86.

Husserl E (1973) Zur Phänomenologie der Intersubjektivität: Texte aus dem Nachlass, Dritter Teil, 1929-35 (=Husserliana XV). Martinus Nijhoff, The Hague, Netherlands

Husserl E (1970) The crisis of European sciences and transcendental phenomenology. Northwestern University Press, Evanston, Carr D (trans)
Kirk GS, Raven JE (1957) The Presocratic philosophers. Cambridge University Press, Cambridge

Merleau-Ponty M (2010) Child psychology and pedagogy. The Sorbonne lectures 1949-1952. Northwestern University Press, Evanston, Welsh T (trans)

Staehler T (2017) Hegel, Husserl and the phenomenology of the historical worlds. Rowman and Littlefield, London

Steinbock AJ (1995) Home and beyond. Generative phenomenology after Husserl. Northwestern University Press, Evanston

Wallace DF (1997) Derivative Sport in Tornado Alley. In: A supposedly fun thing i will never do again. Little Brown and Co., London, p 3-20

Welsh T (2013) The child as natural phenomenologist. Northwestern University Press, Evanston

\section{Data availability}

Data sharing is not applicable to this paper.

\section{Additional information}

Competing interests: The author declares no competing financial interests.

Reprints and permission information is available online at http://www.nature.com/ reprints

Publisher's note: Springer Nature remains neutral with regard to jurisdictional claims in published maps and institutional affiliations.

Change history: This article was originally published under NPG's License to Publish, but has now been made available under a CC BY 4.0 license. The PDF and HTML versions of the paper have been modified accordingly.

(c) (i) Open Access This article is licensed under a Creative Commons Attribution 4.0 International License, which permits use, sharing, adaptation, distribution and reproduction in any medium or format, as long as you give appropriate credit to the original author(s) and the source, provide a link to the Creative Commons license, and indicate if changes were made. The images or other third party material in this article are included in the article's Creative Commons license, unless indicated otherwise in a credit line to the material. If material is not included in the article's Creative Commons license and your intended use is not permitted by statutory regulation or exceeds the permitted use, you will need to obtain permission directly from the copyright holder. To view a copy of this license, visit http://creativecommons.org/ licenses/by/4.0/.

(C) The Author(s) 2017 